of warlike vigour and regionalism, of the Cavalier tradition and the associations of John Peel. But it has been their strange fate to be transformed, in patches here and there, into the industrial slums that sprawl over the West Riding, South Lancashire, the Black Country, and what were once gems of beauty like the Rhondda Valley in South Wales. So it comes about that nests of ancient survivals and hives of nineteenth century industry, not a few now half derelict, are interspersed. And now industry is spreading into the old England of the newer rocks. Have we learned our lesson? Dr. Howarth is hopeful about Corby.

Since 1895, many beauty spots and some four thousand monuments of our past have been placed under the protection of trusts concerned solely with our heritage of beauty and our historic record. This is a worthy record of piety, but it suggests some uncomfortable questions. What will our successors preserve as the records of the Britain of industrial and commercial imperialism? Shall we put a fence around some condemned slum area in Manchester or London and call it a historic monument? Might we not dedicate the slagheaps and discarded railway station of Landore? Are we not perhaps on the way towards sublimating Crewe Junction into the realms of history? Can we not consider a recent suggestion to move the great majority of the statues of booted and frockcoated or robed worthies that encumber rather than adorn our streets and squares into out-of-theway corners of parks?

\title{
The Preservation of Food
}

\section{Canning Practice and Control}

By Osman Jones and T. W. Jones. Pp. xii $+254+$ 65 plates. (London: Chapman and Hall, Ltd., 1937.) 25s. net.

rTHE great changes in the conditions of life brought about by the industrial developments of the last century have necessitated an increased consumption of preserved foods. Of the various processes used in commercial practice, that of sterilizing in hermetically sealed tinplate containers-more commonly referred to as 'canning' - has rightly assumed pride of place, and foods properly preserved in this manner are not only in a form convenient to the housewife but are also at least as nutritious as similar products cooked in the home. The steady growth of the canning industry in size and efficiency has been aided throughout by researches which have covered a wide field, ranging from investigations connected with the growth of suitable raw products through the many problems associated with the technical processes of industry to studies of a more academic nature in bacteriology and metallurgy. It is a little difficult for the general food chemist to keep track of this widespread literature, and for that reason we must welcome any attempt to consolidate the existing knowledge of the science and art of food canning.

The title of the present book is perhaps a little misleading, as there is a noticeable lack of balance between the treatment of the sections on canning practice and laboratory control, and it seems a pity that the authors have limited their discussion of the practical side to about a fifth of the book. On the other hand, the chapters dealing with scientific control as applied to the duties of the works chemist or bacteriologist are more comprehensive than would appear to be necessary.

After a preliminary chapter dealing with the statistics of production and consumption of canned foods, the authors go on to describe the construction and equipment of a cannery and then give a brief outline of canning processes in general. The latter chapter can scarcely fail to be disappointing to the practical canner on account of the many very obvious errors it contains. To take but one example, it is incorrect to say that the majority of canners make their own cans, as almost every firm engaged in the canning of fruits and vegetables obtains its supplies from one of the companies which specialize in making the standard open-top can. Nor are the cans made by these companies supplied in the flattened form, this method of packing being intended only for export purposes.

Adequate space is given to methods of chemical analysis, but greater stress might have been laid on the difficulty of estimating copper in the presence of tin and iron. The bacteriological side of laboratory control occupies about a quarter of the book, and much of the descriptive matter concerning the elementary aspects of the subject could have been omitted with advantage.

The book contains much material of interest and value to the food chemist, the cultural notes on the principal food spoilage organisms being particularly worthy of mention. The text is well supplied with references, and there are many excellent illustrations, the numerous photomicrographs of bacteria being remarkably good.

F. $\mathrm{H}$. 